\title{
Clinical Outbreaks of Bacterial Kidney Disease (BKD) in Hatchery-Raised Brook Trout (Salvelinus fontinalis) (Mitchill, 1814): Lessons Learned
}

\section{Alaa Eldin Eissa ${ }^{1,2 *}$ and Mohamed Faisal ${ }^{3}$}

${ }^{1}$ Department of Fish Diseases and Management, Faculty of Veterinary Medicine, Cairo University, 12211 Giza, Egypt

${ }^{2}$ Department of Poultry and Fish Diseases, Faculty of Veterinary Medicine, University of Tripoli, Tripoli, Libya

${ }^{3}$ Department of Pathobiology and Diagnostic Investigation, Aquatic Animal Health Laboratory (AAHL), College of Veterinary Medicine, Michigan State University, East Lansing, $48824 \mathrm{MI}$, USA

\begin{abstract}
A number of clinical Bacterial Kidney Disease (BKD) outbreaks caused by Renibacterium salmoninarum infection among the hatchery reared brook (BKT) trout lots were presented during 2002-2004 to the Aquatic Animal Health Laboratory, Michigan State University, MI, USA. Diagnosis of these mortality episodes was performed thorough clinical examination, quantitative enzyme-linked immunosorbant assay (Q-ELISA), nested polymerase chain reaction (nPCR), culture, histopathology and immunohistochemistry $(\mathrm{IHC})$. The possible causes that lead to the initiation and progression of such outbreaks have been investigated. Although Q-ELISA, nPCR and culture results for all of the examined cases indicated a heavy infection with $R$. salmoninarum, inconsistent results were obtained by histopathology and immunohistochemical examination of the paraffin embedded blocks of the formalin fixed kidney tissues. This study also included assessment of $R$. salmoninarum infection status in a subsample of BKT broodstocks of the same hatchery. Results indicated the presence of chronic infection in the broodstock with BKDpathognomonic granulomas occupying fairly large portions of the kidney tissues.
\end{abstract}

Keywords: Bacterial kidney disease; BKD; Brook trout; Clinical outbreaks; Immunohistochemistry

\section{Introduction}

Native to North America, the salmonid brook trout (Salvelinus fontinalis) forms an important fishery in the Laurentian Great Lakes [1]. In order to maintain brook trout populations in Michigan, the Michigan Department of Natural Resources raises two strains of brook trout, the Assinica and Iron River strains, for stocking in water bodies where there is a deficiency of natural recruitment [2]. The Assinica brook trout (AS-BKT) strain is characterized by better survival and growth rate [2]. The Iron River brook trout (IR-BKT) strain is a native strain of the Iron River in Michigan's Upper Peninsula. Unlike the Assinica strain, Iron River brook trout are slow to reach maturity and are characterized by a very slow growth rate [3]. Unfortunately, brook trout are especially vulnerable to succumb to the Bacterial Kidney Disease, caused by the Gram positive Renibacterium salmoninarum [4]. R. salmoninarum is an obligate intracellular pathogen with an integral affinity to the hematopoietic tissues of the kidneys. This bacterium secretes a major soluble glycoprotein $(p 57)$ which suppresses the host defense mechanisms of affected fish [5-7].

The first report of BKD in the USA occurred in brook trout at a Massachusetts State fish hatchery [8]. During the late 1940s and early 1950s R. salmoninarum infection caused mass kills in brook trout populations at the state hatcheries in New Hampshire and Cortland [9]. The incidence of BKD in brook trout during succeeding outbreaks in southeastern Wyoming, USA was $100 \%$ and $83 \%$ dead mortal and moribund brook trout, respectively [9]. In Michigan, the first case of BKD was reported in 1955 in brook trout yearlings at the Oden and Marquette state fish hatcheries, where gametes were imported from a state hatchery in New England with known history of BKD [10]. Despite the heightened susceptibility of brook trout to BKD [7-10], description of the mortality episodes and the lesions associated with the infection in this species has received little attention [4]. For this reason, the first objective of this report is to describe the clinical, post mortem, and histopathological observations associated with BKD mortality episodes in the brook trout.
Several antibacterial agents have been recommended for the treatment of clinical BKD in various species of salmonids with different degrees of success. Sulfa-trimethoprim, oxytetracycline, enrofloxacin, florfenicol, and macrolides group of antibiotics (erythromycin and azithromycin) were all tested in vitro and in vivo for their efficacy against $R$. salmoninarum [4]. In particular, erythromycin has been found very effective in reducing mortalities of infected hatchery raised fishes when administered per os along with the food pellets $[3,8]$. While erythromycin has not been approved by the U.S. Food and Drug Administration (FDA), its use in treatment and prophylaxis of BKD is permitted under the New Animal Drug (INAD) Act [4]. Hence, the second objective of the present study was to evaluate the efficacy of erythromycin to stop or reduce mortalities associated with acute BKD course in spontaneously infected brook trout.

Several diagnostic techniques have been developed for the diagnosis of BKD with different degrees of accuracy and specificity [4]. A double antibody sandwich ELISA, is also known as quantitative ELISA (Q-ELISA), provides accurate indication about the real magnitude of BKD in the tested fish population because it determines both prevalence and intensity of the infection [11]. The procedures are fairly standardized by the studies of Pascho and Mulcahy [12]. Polymerase chain reaction (PCR) has been successfully used to detect R. salmoninarum DNA in salmonid kidney tissues, eggs and ovarian fluid [4]. A nested PCR (nPCR) has been developed by Chase and

*Corresponding author: Alaa Eldin Eissa, Department of Fish Diseases and Management, Faculty of Veterinary Medicine, Cairo University, 12211 Giza, Egypt, Tel: 0111185035; E-mail: aeissa2005@gmail.com

Received March 24, 2014; Accepted June 20, 2014; Published June 30, 2014

Citation: Eissa AE, Faisal M (2014) Clinical Outbreaks of Bacterial Kidney Disease (BKD) in Hatchery-Raised Brook Trout (Salvelinus fontinalis) (Mitchill, 1814): Lessons Learned. J Aquac Res Development 5: 242 doi:10.4172/2155 9546.1000242

Copyright: ( 2014 Eissa AE, et al. This is an open-access article distributed under the terms of the Creative Commons Attribution License, which permits unrestricted use, distribution, and reproduction in any medium, provided the original author and source are credited. 
Pascho [13] to amplify a $320 \mathrm{bp}$ fragment of the gene encoding the p57 protein and they recorded no specific fragments amplification when other fish bacterial pathogens were used as templates for nPCR. The sensitivity of the method increased one hundredfold compared to a conventional PCR method [11].

Hoffmann et al. [14] compared various tissue staining techniques (Gram, PAS, IFAT and indirect peroxidase) for their ability to visualize $R$. salmoninarum in the tissues of rainbow trout fixed by various methods (Fresh frozen tissue, frozen formalin- fixed tissue, formalin or Bouin's fixed paraffin-embedded tissue) and concluded that only the indirect peroxidase technique gave satisfactory results regardless of the fixation method used. Since immunohistochemical assays (IHC) may have the advantage of visualizing $R$. salmoninarum and the tissue alteration they cause simultaneously [14], the third objective of this study was to apply IHC assay to in situ detect $R$. salmoninarum and its antigens in kidneys of spontaneously infected brook trout.

In this context, Evensen et al. [15] reported on their success in detecting $R$. salmoninarum in situ using paraffin embedded tissue specimens from infected Atlantic (Salmo salar). However, it has been reported that extended preservation of tissue samples in formalin has deleterious effect on the antigen detection and retrieval in IHC [14]. Hence, the fourth objective of this study was to determine if the antigen capture technique can improve the visualization of $R$. salmoninarum in long preserved paraffin-embedded tissues of infected brook trout.

\section{Material and Methods}

\section{Fish sampling}

A number of BKD outbreaks involving brook trout were investigated between the years of 2002 and 2004:

In April 2002, a total of 60 Iron River brook trout (IR-BKT yearlings were submitted to the Aquatic Animal Health Laboratory (AAHL) at Michigan State University from the Marquette State Fish Hatchery (MSFH) in Michigan for disease investigation. Clinical and laboratory diagnoses were performed on the fish to identify the cause of mortalities.

In May 2003, a total of 72 IR-BKT yearlings with a recent history of mortalities were submitted to AAHL. Clinical and laboratory diagnosis were performed on the fish to identify the cause of mortalities. A course of treatment was prescribed and followed by the collection of another 60 samples for post treatment analysis.

In July 2004, a total of 9 adult three year-old Assinica brook trout (AS-BKT) were submitted to the AAHL from the MSFH during an onset of broodstock losses.

In September 2004, a total of 30 brook trout yearlings were submitted to the AAHL from Michigan private fish farm experiencing increased mortalities.

\section{Clinical examination}

Clinical examination was performed as per the American Fisheries Society's Blue Book guidelines [1]. Briefly, fish in raceways were examined for their swimming behavior, food intake, and aggregations around water inlets and outlets. Lethargic and apparently normal fish were examined for vital reflexes and external lesions. A sample of the fish were then sacrificed using an overdose of tricaine methane sulfonate (MS 222, Finquel - Argent Chemical Laboratories, Washington) and examined externally for the presence of any lesions, parasites, or abnormal growths on the skin or gills. Fish were dissected and examined internally and abnormalities in internal organs were recorded.

In order to determine the presence of external parasites, wet mounts were prepared from skin and gill as well as from abnormal lesions in internal organs and then examined microscopically (100 X and $400 \mathrm{X}$ magnifications) to check for the presence of parasites or fungi.

\section{Sample processing}

Kidney samples were aseptically transferred into sterile $7.5 \mathrm{~cm} \mathrm{x}$ $18.5 \mathrm{~cm}$ Whirl Pak ${ }^{\otimes}$ bags (Nasco, Forte Atkinson, WI), kept on ice, and were softened as much as possible through multiple cycles of physical pressure. The homogenized kidney tissues were diluted in 1:4 (w/v) Hank's Balanced Salt Solution (HBSS, Sigma, St. Louis, MO) then stomached for 2 minutes at high-speed in a Biomaster Stomacher-80 (Wolf Laboratories Limited, Pocklington, York, UK) as described in Faisal et al. [16].

\section{Culture}

Isolation of R. salmoninarum was performed as described by Faisal et al. [16]. Briefly, $100 \mu \mathrm{l}$ of stomached kidney tissue aliquots were spread onto Modified Kidney Disease Medium (MKDM) agar plates modified by Eissa [4] and incubated at $15^{\circ} \mathrm{C}$ for a period of 10 days. Cultured plates were checked every 5 days for any bacterial growth. Identification of the isolates was done according to the standard morphological and biochemical criteria of $R$. salmoninarum [17]. A number of biochemical tests on each isolate were performed including motility, using motility test medium (DIFCO- BD and Company Sparks, MD, USA), cytochrome oxidase with Pathotec strips (Remel, USA), catalase test with $3 \%$ hydrogen peroxide, hydrolysis of esculin using bile esculin agar (Remel), and DNAse test using DNAse test medium (Remel). Carbohydrate utilization was performed using basal media (DIFCO-BD). The basal medium was prepared according to manufacturer instructions prior to the addition of individual sugars. Ten $\mathrm{ml}$ of $0.45 \mu \mathrm{m}$ filter sterilized $10 \%$ sugar solution was added to autoclaved and cooled $\left(48^{\circ} \mathrm{C}\right)$ basal media to obtain a final concentration of $1 \%$ with the exception of salicin which was made as $5 \%$ solution to reach $0.5 \%$ final concentration. Each one of the following sugars was added individually to the basal medium to test for the utilization of each sugar: arabinose, glucose, lactose, maltose, rhamnose, salicin, sucrose, sorbitol, xylose. All sugars were from Sigma. Results of biochemical tests were matched against standard $R$. salmoninarum biochemical characters described earlier $[4,17]$.

\section{Measurements of Renibacterium salmoninarum antigens us- ing the Quantitative Enzyme-linked Immunosorbent Assay (Q-ELISA)}

The Q-ELISA method used in this study is that described in details by $[11,12]$. The positive negative threshold absorbance is calculated using the method described by [18]. The positive-negative demarcation absorbance for the tissue homogenate was 0.10 . The tested positive kidney tissue samples were given the following antigen level classes: low (0.10 to 0.19$)$, medium (0.20-0.99) and high (1.000 or more) [19]. The magnitude of BKD was presented as the percentage of fish with high titers of $R$. salmoninarum antigens.

\section{Nested Polymerase Chain Reaction (nPCR)}

A Qiagen DNeasy tissue extraction kit (Qiagen-Valencia, CA USA) was used for the extraction of DNA from brook trout kidney homogenates. The DNA was isolated according to the manufacturer's 
instructions, with a few minor modifications from the method described by [11]. The tissue sediment was obtained by spinning at $6000 \mathrm{rcf}$ for 20 minutes at $4^{\circ} \mathrm{C}$. The sediment were further incubated with lysozyme buffer consisting of $180 \mu \mathrm{l}$ of $20 \mathrm{mg}$ lysozyme (Sigma), 20mM Tris-HCl, pH 8.0; 2 mM EDTA (Sigma) and 1.2\% (v/v) Triton X 100 (Sigma) at $37^{\circ} \mathrm{C} / 1$ hour. The $\mathrm{nPCR}$ procedures and specific primers recommended by [11] were utilized. The controls were composed of a PCR mixture containing DNA free reagent (negative control), positive R. salmoninarum strain and positive tissue control. The PCR products were eletrophoresed in 2\% agarose gel (Invitrogen Life Technologies, Carlsbad, CA), stained with ethidium bromide, visualized with ultraviolet light, and photographed using a Kodak EDAS system (Eastman Kodak, Rochester, NY). Samples were considered positive when a $320 \mathrm{bp}$ band was detected. Molecular confirmation of the purified bacterial isolates was also performed using nPCR according to the method described by [13].

\section{Histopathology}

Kidney tissues fixed in $10 \%$ neutral buffered formalin solution were processed and embedded in paraffin. Five-micron sections were routinely stained with Hematoxylin and Eosin $(\mathrm{H} \& \mathrm{E})$ using the method previously described by [20]. Slides were evaluated and given a score of $0,+1,+2$, or +3 based on degree of pathological alterations.

\section{Immunohistochemistry (IHC)}

The methods used in the IHC followed the protocol detailed elsewhere [14]. In brief, tissue sections of kidney from brook trout with clinical signs were used for immunohistochemical evaluation of the expression $R$. salmoninarum soluble antigens. IHC staining was performed on automated immuno-stainers. Paraffin embedded tissues that had been fixed in formalin for less than 48 hours were deparaffinized in xylene, rehydrated in graded ethanol, and rinsed in distilled water. Endogenous peroxidases were neutralized with 3\% hydrogen peroxide for 5 minutes. Antigen unmasking was achieved by incubating slides in a citric buffer antigen unmasking solution in a steamer (Black \& Decker, Towson, MD) for $20 \mathrm{~min}$, and non-specific immunoglobulin binding was blocked by incubation of slides for $10 \mathrm{~min}$ with a proteinblocking agent (Dako, Carpinteria, CA). Using the autostainer (Dako), slides were incubated for 30 minutes with a goat anti- $R$. salmoninarum antibody (Kirkegaard \& Perry Laboratories) at a dilution of 1:100. A streptavidin-immunoperoxidase staining procedure (Dako) was used for immunolabeling. The immune-reaction was visualized with AEC (Dako). Sections were counterstained with Mayer's hematoxylin. Tissues that had been fixed in formalin for more than a year were immunostained using the protocol described above as well as the following method to enhance antigen unmasking. In this particular protocol deparaffinization, antigen retrieval, and immunostaining of formalin-fixed paraffin embedded tissues were performed on the Bench Mark Automated Staining System (Ventana Medical Systems, Incorporation) using the Enhanced V-Red (Alkaline Phosatase Red) Detection System (Ventana Medical Systems Incorporation) and a goat anti R. salmoninarum antibody (Kirkegaard \& Perry Laboratories) at a dilution of 1:100.

Antigen retrieval was achieved using the Ventana Medical Systems Unmasking Solution CC1 (Ventana Medical Systems) for $60 \mathrm{~min}$ followed by digestion with and Protease 3 for $4 \mathrm{~min}$ (Ventana Medical Systems). Sections were counterstained with hematoxylin. Positive IHC controls included a kidney from a trout with strong $R$. salmoninarum soluble antigens expression to which the appropriate antisera were added. For negative controls the primary antibodies were replaced with homologous non-immune sera.

\section{Treatment trial}

A daily dose of $70 \mathrm{mg} / \mathrm{Kg}$. b.wt., erythromycin medicated feed (erythromycin phosphate: 4.5\% Aquamycin-100) were used for 10 successive days to control the disease among the sick fish and the apparently normal fish. The curve of mortalities decreased gradually until the mortalities completely ceased within few days. Representative samples from the fresh live treated fish as well as freshly dead fish were retested using culture, Q-ELISA and nPCR.

\section{Virological examination}

In order to exclude viral infection, kidney homogenates were further diluted 1:50 in Hanks Balanced Salt Solution (HBSS-Sigma) and then streaked over $24 \mathrm{hr}$ old monolayers of Fathead Minnow (FHM) and Chinook Salmon Embryo (CHSE) cell lines. Inoculated cells were incubated at $25^{\circ} \mathrm{C}$ for FHM and $15^{\circ} \mathrm{C}$ for CHSE cell lines. The cells were examined daily for the development of cytopathic effects for two weeks, and when not present, a blind passage was performed as per the guidelines of the American Fishery Society's guideline [1]

\section{Results}

A number of BKD outbreaks erupted among hatchery-raised brook trout during 2002 and 2004. In April, 2002, increased mortalities were reported in IR-BKT strain at MSFH. Mortality was as high as $30 \%$ of the fish in the affected populations. Externally, all fish submitted for clinical examination showed shallow ulcerations in different parts of body especially on nuchal regions and sides (Figure 1). External parasitic examination revealed heavy infestations of the skin with the monogenean Gyrodactylus salmonis, sessile ciliates and Trichodina species. Internally, the majority of fish exhibited typical signs of BKD, such as enlarged kidneys with whitish gray discoloration and the presence of multiple creamy whitish nodules scattered throughout the kidney tissues (Figure 2).

Results of the cell line inoculation have revealed an absence of any possible cytopathic effects on both FHM and CHSE cell lines, which confirm that all tested fish samples were free from fish specific viruses detectable on those cell lines.

Kidney homogenate samples were tested for R. salmoninarum using nPCR, Q-ELISA and bacterial culture. Results indicated that $R$. salmoninarum was present in all samples using each of the three techniques. All tested fish had high concentration of $R$. salmoninarum antigens in the kidney tissue by Q-ELISA.

Examination of the histological sections stained with $\mathrm{H} \& \mathrm{E}$ of affected kidneys revealed the presence of typical granulomatous

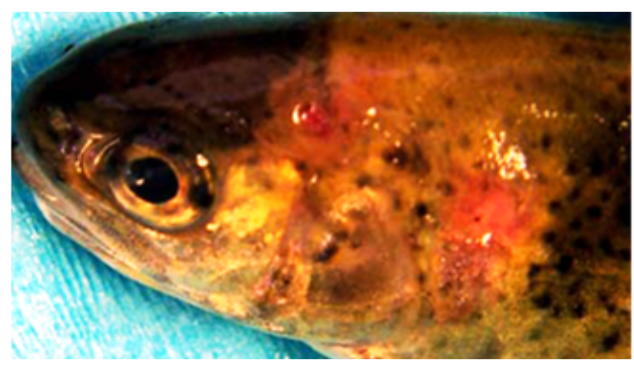

Figure 1: Iron River brook trout fingerling with skin erosions and shallow ulceration. 
Citation: Eissa AE, Faisal M (2014) Clinical Outbreaks of Bacterial Kidney Disease (BKD) in Hatchery-Raised Brook Trout (Salvelinus fontinalis) (Mitchill, 1814): Lessons Learned. J Aquac Res Development 5: 242 doi:10.4172/2155-9546.1000242

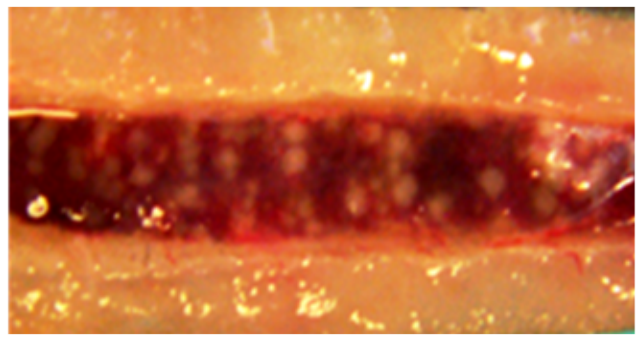

Figure 2: Iron River brook trout fingerling showing the pathognomonic lesions of BKD: swollen kidney with multiple creamy whitish nodules.

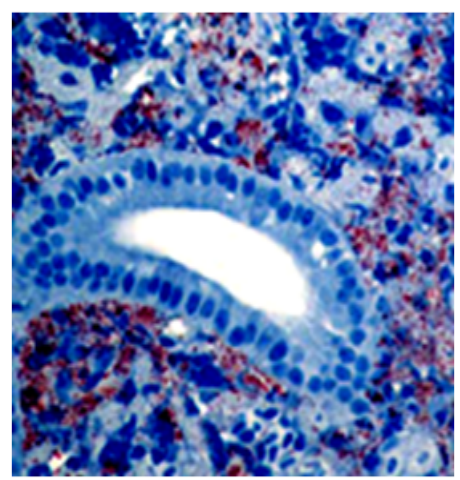

Figure 3: Kidney tissue of Iron River brook trout fingerling exhibiting heavy Renibacterium salmoninarum infection. Kidney sections were stained using an anti-Renibacterium salmoninarum antibody based streptavidin immunoperoxidase immunolabeling (Magnification 400). Sections were counterstained with Mayer's hematoxylin (Blue background) while $R$. salmoninarum and its antigens were stained red. Notice the involvement of the kidney's hematopoietic tissues with the kidney tubules devoid antigens.

reactions with a necrotic center that was surrounded by a fibrous capsule, with a mixture of epithelioid macrophages, lymphocytes, and frequent giant cells. Gram-positive coccobacilli were observed within the necrotic tissue as well as other layers of the granuloma. When immunohistochemical (IHC) procedures were performed on the paraffin-waxed kidney sections, high positive results (scored $3+$ ) where bacterial cells taking the dark red IHC staining were heavily distributed within the blue background of the kidney tissues (Figures 3 and 4). A trial for treatment of the external parasites with formalin followed by erythromycin treatment didn't improve the situation. Because of the bad health status of the examined fish, the infected fish lot was advised to be eradicated.

In May 2003, similar episode of infection occurred in the fingerlings of the IR-BKT strain from MSFH. The fish were examined using clinical and laboratory methods and a diagnosis of BKD with Gyrodactylus salmonis infestation was reached. Formalin treatment was applied to control external parasites. Treatment was begun using (Aquamycin-100) erythromycin dose of $75-150 \mathrm{mg} / \mathrm{kg}$ of fish weight was implemented in compliance with Investigational New Animal Drug (INAD) specifications to control the BKD infection. Mortalities gradually decreased along the treatment course until completely subsided upon completion of treatment. In early June of 2003, a total number of 60 erythromycin treated IR-BKT fingerlings were further examined post treatment. Results showed 4 out of 60 fish (6.7\%) still had clinical BKD lesions. Kidneys of the examined fish were tested for the presence of $R$. salmoninarum antigens using Q-ELISA. Results indicated that $R$. salmoninarum antigens had sharply declined to $18.3 \%$, with only $5 \%$ demonstrating the high titer of the antigens. Culture from post treatment fish showed that only 4 out of 60 fish (6.7\%) were positive.

In mid-July of 2004, mortalities in the 3 year-old Assinica strain of brook trout stocks in MSFH continued for a month before representative samples were submitted for investigation. Random samples from fish in affected raceways were externally examined, where skin scraping revealed heavy infestations with the monogenean Gyrodactylus salmonis. A total of 9 clinically affected fish were examined, where 7 out of 9 fish (77.8\%) exhibited heavy Gyrodactylus salmonis, sessile ciliates and fungal hyphae. Internally, 5 out 9 fish (55.6\%) exhibited grayish discoloration of the kidneys, with the presence of white abscess-like nodules scattered throughout the kidneys. Kidney samples from the 9 fish were further tested using nPCR, Q-ELISA and culture. All samples were positive when tested using nPCR, while a total number of 7 out of 9 (77.8\%) fish were culture positive and 3 out of 9 fish $(33.3 \%)$ were Q-ELISA positive ( 1 high, 1 medium, 1 low). When submitted for histopathology, $75 \%$ of the kidney samples exhibited moderate multi-focal granulomatous reactions (scored 1+) and 25\% exhibited severe multi-focal granulomatous reactions (Scored 3+) (Figure 5). The reactions were characterized by the presence of typical granulomas, accompanied by a mixture of epithelioid macrophages, lymphocytes

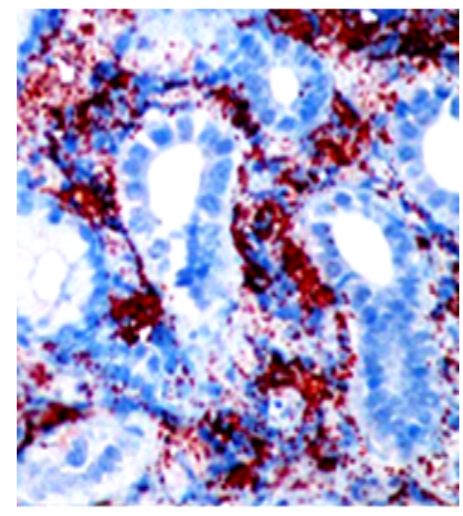

Figure 4: Kidney tissue of Iron River brook trout fingerling exhibiting heavy Renibacterium salmoninarum (red) infection after enhanced antigen retrieval procedures using Alkaline Phosphatase Red and goat anti-Renibacterium salmoninarum antibody. Sections were counterstained with Mayer's Hematoxylin (Blue background) (Magnification 400). Notice that despite the heavy infection in the kidney's hematopoietic tissues, kidney tubules remain free of $R$. salmoninarum antigens.

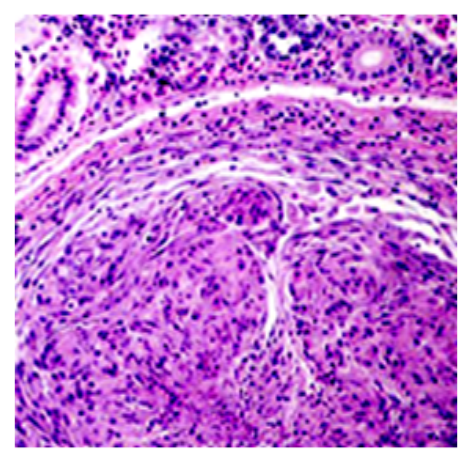

Figure 5: Hematoxylin and Eosin stained slide of kidney showing a severe granulomatous reaction that is replacing kidney tissues in BKT. Notice the fibrous capsule surrounding the entire granuloma (Magnification 100). 
and occasional giant cells. Interestingly, the granulomatous reaction replaced $50-60 \%$ of the renal parenchyma (Figure 5). Centrally, the lesion was composed of eosinophilic, caseous debris, surrounded by marked sheets, nests, and laminated foci of epithelioid macrophages mixed with lymphocytes. The periphery of the lesion was surrounded by mature fibrous connective tissue associated with more destruction of the renal parenchyma (Figure 5). Despite the fact that most of the samples showed the presence of typical granulomatous inflammation with varying severity ( $1+$ to $3+$ scores), the results of the IHC technique performed on the paraffin-waxed lesions were negative. The only sample with a typical granulomatous reaction exhibited very few bacterial cells when the antigen retrieval technique was performed on the paraffin embedded blocks of the same samples (Figure 6).

In Mid-September of 2004, mass mortalities occurred in the brook trout yearlings of a private brook trout farm. Mortalities continued for two weeks before submission of fish to the AAHL for disease investigation. External parasitological examination of fish gills and skin revealed the presence of large numbers of the monogenean Gyrodactyllus salmonis and sessile ciliates. Internally, 12 out of 30 fish (40\%) showed pale gray, whitish discolorations and swelling of the kidneys, with multiple abscess-like nodules scattered all over the kidneys. Typical colonies of $R$. salmoninarum were observed after 2 weeks on MKDM from a total of 18 out of 30 fish $(60 \%)$. The retrieved colonies were later confirmed as $R$. salmoninarum using nPCR. The concomitant use of Q-ELISA on the same kidney tissue homogenates showed that 18 out of 30 fish $(60 \%)$ were positive for $R$. salmoninarum antigens, with an intensity of $67 \%$ (expressed by percent of fish with high titers of $R$. salmoninarum soluble antigens using Q-ELISA).

\section{Discussion}

For decades, brook trout have been known for their high susceptibility to R. salmoninarum infection [7-10]. Brook trout infected with $R$. salmoninarum either naturally or experimentally suffer from high mortalities [7-10]. BKD outbreaks were associated with severe clinical signs and high mortalities in brook trout in Michigan. The frequent occurrence of BKD epizootics in hatchery raised brook trout populations during 2002 and 2004 without affecting other salmonids, such as the lake trout residing in the same hatchery, presumptively indicates that brook trout have higher susceptibility to R. salmoninarum infection when compared to other char and trout species. Although

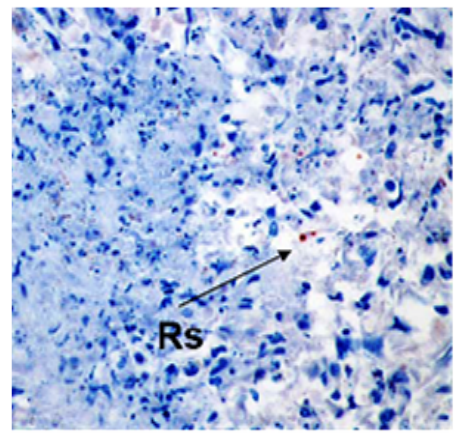

Figure 6: An immunohistochemistry of Kidney tissue sections of broodstock fish exhibiting chronic multi-focal granulomatous reactions: Notice the presence of $R$. salmoninarum and its antigens (red). Slides were stained using the ter enhanced antigen retrieval procedures using Alkaline Phosphatase as the markers and goat anti-Renibacterium salmoninarum antibody. Sections were counterstained with Mayer's Hematoxylin (Blue background) (Magnification 400).

Rs: Renibacterium salmoninarum soluble antigens with the red staining affinity. brook trout are known for their high susceptibility to R. salmoninarum infection [7-10], reports of the disease in this species were scarce in Michigan.

Data indicated that the clinical picture and the magnitude of the mortalities described in the current study coincide with previous reports about BKD-associated epizootics in brook trout in the United States [710]. Outbreaks described in the current study were frequently coupled with external parasitic infestations. It is not clear whether the external parasitic infestation initiated or resulted from the BKD infection and subsequent mortalities. Meticulous observation of the results indicated that many factors were involved in influencing mortalities associated with the outbreaks. For example; all outbreaks reported in the current study occurred at the time of year during which the water temperature is fluctuating with some indication of water temperature increase (spring, early, mid and late summer).

Previous studies indicated that the rise in water temperature, along with the heavy density in the hatchery raceways, favors the external parasites [21,22]. In addition, heavy external parasitic infestations open portals of entry within the skin and gills of fish and facilitate the horizontal transmission of the R. salmoninarum in water via the skin and gills. It is well documented that the bacteria can survive in water and feces for up to 21 days $[23,24]$. Also, a number of authors have hypothesized that water and feces indirectly act as reservoir for the transmission of R. salmoninarum from infected fish to other fish [9]. Combining all factors, the assumption of existence of the fish in a pool of bacteria which able to enter through the skin and gill wounds created by external parasites couldn't be excluded. Alternatively, the gradual increase of water temperature during the time of the outbreaks was assumed by some authors to initiate the progression of BKD infection $[7,8,24]$. The sequence of BKD infections is usually associated with the production of $R$. salmoninarum soluble antigens, which are known to suppress the immune response of infected fish [5-7].

Immunosuppression associated with BKD infection might drive the host to become vulnerable to infection by other pathogens including external parasites.

The development of the disease in the 2002-2004 outbreaks was documented using both histopathology and IHC. Examination of kidney sections stained with $\mathrm{H} \& \mathrm{E}$ indicated the presence of severe granulomatous reactions, with typical granuloma components where the organism could be detected both intra- and extra-cellularly using the Gram stain. Previous records of histopathology support these findings [25-27]. In case of the Iron River BKT mortalities, IHC stained slides indicated the presence of an intense distribution of bacterial cells and their antigens within the kidney tissues, as well as within the granulomas, which confirms the assumption that the severe progression of the disease is associated with high bacterial metabolic activities [2628]. Similar findings were reached by $[14,15]$. Some discrepancies were observed between histopathological findings (positive with different scores) and IHC results (negative results with some of positive histopathological changes). The histopathological findings ranged from mild multi-focal histiocytic inflammation (scored 1+), which appeared negative using the IHC stains to severe granulomatous reaction replacing more than $60 \%$ of the kidney parenchyma (scored $3+$ ). These kidney sections were negative when tested using regular IHC procedures and turned into very low positive after improved antigen retrieval procedures were performed. It is difficult to interpret the discrepancies between the IHC and histological results, however some assumptions could be proposed. 
Kidney samples were preserved in buffered formalin solution for more than 1 year which is reported to be a crucial factor in reducing the sensitivity of IHC techniques for many antigens and epitopes $[29,30]$. This long time preservation in buffered formalin solution could produce denaturation of the soluble antigens (p57 protein) and formation of Methylene bridges, both inter and intra-molecularly which will ultimately alter the physical characteristics of the kidney tissues and also induces masking of the antigens (p57) [30]. These deleterious effects of formalin might be a good cause for the inability to detect the bacterial cells within the affected kidney tissues using IHC, although they were positive with other techniques like Q-ELISA, culture, and $\mathrm{nPCR}$. An enzymatic digestion and heat treatment methods (antigen retrieval methods) [30] were used intensively to retrieve the masked antigens from the IHC processed tissues. Unfortunately, the antigen retrieval methods were only able to retrieve few $R$. salmoninarum soluble antigens within a typical granulomatous reaction of kidney tissue. One important disadvantage of the antigen retrieval method using heat treatment is the unexpected dissociation of the major soluble antigen (p57), which is known to be heat labile [30].

\section{Conclusion}

This study supports the previous reports, which emphasized that brook trout are highly susceptible to $R$. salmoninarum infection and brings up an important fact that BKD became an enzootic disease in both Michigan feral and captive brook trout populations. In addition, this study shed light on the possible contribution of a number of factors to development of BKD epizootics in Michigan hatcheries, such as the seasonal changes and the presence of external parasites. Further, research has proved that erythromycin phosphate was a very efficient INAD drug in combating clinical BKD outbreaks. Finally, the last section of the study presented a novel comparative pattern on the efficacy of histopathology and immunohistochemistry in relative detection of the bacterial pathogens within the long term formalin fixed tissue specimens.

\section{Acknowledgments}

This research was supported by a grant from the Great Lakes Fishery Trust, Lansing, Michigan, USA. The authors express their appreciation to current and previous personnel of the Michigan Department of Natural Resources and Michigan State University Aquatic Animal Health Laboratory for their help with sampling and performing diagnostic assays.

\section{References}

1. AFS-FHS (American Fisheries Society-Fish Health Section) (2007) FHS Blue Book: Suggested Procedures for the Detection and Identification of Certain Finfish and Shellfish Pathogens, 2007 Edition. AFS-FHS, Bethesda, Maryland.

2. Dexter JL, O'Neal P (2004) Michigan Fish Stocking Guidelines II: With Periodic Updates." State of Michigan, Department of Natural Resources, Fisheries Division Special Report 32: 67.

3. Gowing $H$ (1986) Survival and Growth of Matched Plantings of Assinca Strain Brook Trout and Hybrid Brook Trout (Assinca X Domestic Female) in Six Smal Michigan Lakes. North Am J Fish Management 6: 242-51.

4. Eissa AE (2005) Bacterial Kidney Disease (BKD) in Michigan Salmonids. Phd Dissertation. Michigan State University, East Lansing, Michigan. 210.

5. Ellis AE (1999) Immunity to Bacteria in Fish. Fish Shellfish Immunol 9: 291-308.

6. Fredriksen A, Endresen C, Wergeland HI (1997) Immunosuppressive Effect of a Low Molecular Weight Surface Protein from Renibacterium salmoninarum on Lymphocytes from Atlantic Salmon (Salmo salar L.). Fish Shellfish Immunol 7: 273-82.

7. Grayson TH, Coopers LF, Wrathmell AB, Roper J, Evenden AJ, Gilpin ML (2002) Host Responses to Renibacterium salmoninarum and Specific Components of The Pathogen Reveal The Mechanisms of Immune Suppression and Activation. $\mathrm{J}$ Immunol 106: 273-83.
8. Belding DL, Merrill B (1935) A Preliminary Report Upon a Hatchery Disease of the Salmonidae. Trans Am Fish Soc 65: 76-84.

9. Snieszko SF, Griffin PJ (1955) Kidney Disease in Brook Trout and its Treatment Prog Fish Cult 17: 3-13.

10. Allison LN (1958) Multiple Sulfa Therapy of Kidney Disease among Brook Trout. Prog Fish Cult 20: 66-8.

11. Pascho RJ, Chase D, Mckibben CL (1998) Comparison of the MembraneFiltration Fluorescent Antibody Test, The Enzyme-Linked Immunosorben Assay and The Polymerase Chain Reaction To Detect Renibacterium salmoninarum in Salmonid Ovarian Fluid. J Vet Diagn Invest 10: 60-6.

12. Pascho RJ, Mulcahy D (1987) Enzyme-Linked Immunosorbent Assay for a Soluble Antigen of Renibacterium salmoninarum, The Causative Agent of Salmonid Bacterial Kidney Disease. Can J Fish Aquat Sci 44: 183-91.

13. Chase DM, Pascho RJ (1998) Development of a Nested Polymerase Chain Reaction for Amplification of a Sequence of The P57 Gene of Renibacterium salmoninarum That Provides a Highly Sensitive Method for Detection of the Bacterium in Salmonid Kidney. Dis Aquat Org 34: 223-9.

14. Hoffmann RW, Bell GR, Pfeil-Futzien C, Ogawa M (1989) Detection of Renibacterium Salmoninarium in Tissue Sections by Different Methods a Comparative Study with Special Regard to the Indirect Immunohistochemical Peroxidase Technique. Fish Pathol 24: 101-4.

15. Evensen O, Dale OB, Nilsen A (1994) Immunohistochemical Identification of Renibacterium salmoninarum by Monoclonal Antibodies in Paraffin-Embedded Tissues of Atlantic Salmon (Salmo salar L.), Using Paired Immunoenzyme and Paired Immunofluorescence Techniques. J Vet Diagn Invest 6: 48-55.

16. Faisal M, Eissa, AE, Starliper CE (2009) Recovery of Renibacterium salmoninarum from Naturally Infected Salmonine Stocks in Michigan Using a Modified Culture Protocol. J Adv Res 1: 95-102.

17. Sanders JE, Fryer JL (1980) Renibacterium salmoninarum Gen. Nov., Sp Nov., The Causative Agent of Bacterial Kidney Disease in Salmonid Fishes. Intern J System Bacteriol 30: 496-502.

18. Alcorn SW, Pascho RJ (2000) Single-Dilution Enzyme-Linked Immunosorbent Assay for Quantification of Antigen-Specific Salmonid Antibody. J Vet Diagn Invest 12: 245-52.

19. Meyers TR, Short S, Farrington C, Lipson K, Geiger HJ, Gates R (1993) Establishment of Negative-Positive Threshold Optical Density Value for the Enzyme-Linked Immunosorbent Assay (ELISA) To Detect Soluble Antigen of Renibacterium salmoninarum in Alaskan Pacific Salmon. Dis Aquat Org. 16 191-7.

20. Prophet E, Mills B, Arrington J (1992) Laboratory Methods in Histotechnology Armed Forces Institute of Pathology 131-2.

21. Mo TA (1997) Seasonal Occurrence of Gyrodactylus derjavini (Monogenea) on Brown Trout, Salmo trutta, and Atlantic Salmon, S. salar, in The Sandvikselva River, Norway. J Parasitol 83: 1025-1029.

22. Rintamaki P, Valtonen ET (1994) Occurrence of Gyrodactylus salaris at Four Fish Farms in Northern Finland. University of California, School of Veterinary Medicine, Davis, CA, USA. 13.1.

23. Austin B, Rodgers CJ (1980) Diversity Among Strains Causing Bacterial Kidney Disease in Salmonid Fish. Curr Microbiol 3: 231-5.

24. Balfry SK, Albright LJ, Evelyn TPT (1996) Horizontal Transfer of Renibacterium salmoninarum Among Farmed Salmonids Via The Fecal-Oral Route. Dis Aquat Org 25: 63-9.

25. Smith IW (1964) The Occurrence and Pathology of Dee Disease. Freshwater Salmon Fish Res 34: 1-13.

26. Sami S, Fischter-Scherl T, Hoffman RW, Pfeil-Putzien C (1992) Immune Complex Mediated Glomerulonephritis Associated With Bacterial Kidney Disease in the Rainbow Trout (Oncorhynchus mykiss). Vet Pathol. 29: 169-74.

27. Wood EM, Yasutake WT (1956) Histopathology of Kidney Disease in Fish. Am J Pathol 32: 845-57.

28. Young CL, Chapman GB (1978) Ultrastructural Aspects of the Causative Agent and Renal Histopathology of Bacterial Kidney Disease in Brook Trout (Salvelinus fontinalis). J Fish Res Board Can 35:1234-48. 
Citation: Eissa AE, Faisal M (2014) Clinical Outbreaks of Bacterial Kidney Disease (BKD) in Hatchery-Raised Brook Trout (Salvelinus fontinalis) (Mitchill, 1814): Lessons Learned. J Aquac Res Development 5: 242 doi:10.4172/2155-9546.1000242

Page 7 of 7

29. Evenden AJ, Grayson TH, Gilpin ML, Munn CB (1993) Renibacterium salmoninarum and Bacterial Kidney Disease-The Unfinished Jigsaw. Ann Rev Fish Dis 3: 87-104
30. Sompuram SR, Vani K, Messana E, Bogen SA (2004) A Molecular Mechanism of Formalin Fixation and Antigen Retrieval. Am J Clin Pathol 121: 190-9. 